\title{
People, ideas and stories of soils research: a brief overview
}

\author{
Stepan Pozniak ${ }^{1 *}$, Natalia Havrysh ${ }^{2}$ \\ ${ }^{1}$ Ivan Franko National University of Lviv, Faculty of Geography, Department of Pedology and Geography of Soil, 41 Doroshenka St., Lviv, 79000 , \\ Ukraine \\ ${ }^{2}$ National University “Odessa Law Academy”, Department of Agricultural, Land and Environmental Law, Pionerska St. 2, 65009, Odessa, Ukraine \\ * Prof. S. Pozniak, stepan.pozniak@lnu.edu.ua, ORCID iD: https://orcid.org/0000-0002-3012-1159
}

Received: 18.11.2020

Accepted: 21.04.2021

Associated editor: C. Kabała

\section{Keywords}

\section{Soil}

Soil resources

Social soil science

Soil informativeness

Soil protection

Soil fertility

\begin{abstract}
The article highlights the exceptional importance of soils in the modern world and the importance of scientific research in soil science, which can be an important means of solving social problems. It is shown that soil resources, as the basis of agricultural development, are the long-term capital through which different nations exist and develop. The current state of soils can serve not only as a characteristic of the development of society, but also as a criterion for assessing the activities of government and social stability of the country.
\end{abstract}

\section{Introduction}

Soil is something special and extremely important in nature and human life, which can be traced back to the times of Mesopotamia, when people were believed to have been created by God from soil. The history of life of the planet is inextricably connected with the history of the soil. The evolution of ancient soils has indeed played a key role in transforming of our planet into a place suitable for more complex life forms. The evolution of plants has increased the intensity of soil formation, which has led to the appearance of soils which are capable of better life support for more plants. Thus, the soil is a kind of interface between the native rocks that make up our planet and wildlife, plants and animals that exist due to sunlight and nutrients which are formed as a result of weathering.

The terrestrial life, in its very essence needs soil, which, in turn, is life and produces with the participation of organic. Soil is a hospitable home for both plants and people. Actually, life creates the soil then the soil creates new life. Such a pair of phrases can describe the past half billions of years of our history. Plants which evolved and overland life forms nourished the soil, and the soil, in its turn, nourished these plants, which served as nutriment for more complex groups of animals. Life and soil were partners until modern farming methods changed the rules of the game. How long will agriculture in its current form will be able to sustain our lives by developing the connections between soil and life? If we consider this question on the scale of any geologically significant time scale, an exhaustive agrarian civilization will not be long-lasting - it simply will not be able to exist, destroying its own foundation. It is necessary to look at the soil in a different way - to stop seeing it just as a substrate for growing plants and ensuring their prosperity. We need to adapt to the soil as an ecosystem, not try to adapt the soil to our needs, so that later, when the fertile soil becomes a sterile substance, we try to compensate damages with the help of fertilizers and biocides.

\section{Soil as a dynamic system}

Developing the concept of soil as a dynamic layer at the junction of rocks and living organisms, Charles Darwin stated that the thickness of the soil layer reflects environmental conditions. The soil layer thickens until there is an equilibrium between the rate of soil erosion and the rate of soil formation, during which the rocks that come to the surface are transformed into new fertile soil. Thus, the soil is a dynamic system that reacts to changes in the environment (Darwin, 1881; Johnson et al., 2015). 
From ancient times to the present day in various aspects (scientific, practical, philosophical, spiritual, religious, etc.) a close relationship and interdependence between soil and man in all eras of human society development. Based on the study of ancient Latin texts, Winiwarter determines that the farmers of ancient Rome considered the soil as a dynamic variable living creature that plays in nature no less a role than human. At the same time, there was an awareness that human prosperity is impossible without careful treatment of the soil and its proper cultivation (Winiwarter, 2004).

Based on the analysis of ancient mythology, stages of people's attitude to the environment, ethnoecology and ecology, it can be argued that in ancient Greek, Chinese and Jewish sources, the soil is always considered in certain religious and cultural contexts.

In the basic texts of the Christian religion it is said about the fundamental connection between human and soil. In Hebrew, the name of the first man, Adam, is derived from the word “adama”, meaning earth, soil. As Adam's wife's name, Eve, comes from the word hava, which in Hebrew means "the one who gives life," the union of earth and life linguistically reflects the basis of the biblical story of the creation of the world. The Lord created the soil - Adam, and the life - Eve - was originated from the Earth - the ribs of Adam. The Latin which means man - homo - comes from the word humus, translated from Latin “above-ground layer of soil” (Montgomery, 2007).

The loss of soil resources is typical not only for ancient civilizations, but it is also a threat for modern society. Throughout almost all historical period, soils occupied the main place in human culture. The history about soils dates back thousands of years. It contains a lot of interesting and important information, as it is inextricably connected with the development of agriculture and humanity in general.

\section{Soil as an environment for growth and cultivation of plants}

The main feature of the primary accumulation of disparate facts about the properties of soils, their fertility and methods of cultivation is a human awareness of the soil as an environment for plant growth and cultivation, as well as understanding the great diversity of soils and the need for differentiated use in agriculture and different taxation (Pozniak et al., 2015).

Historical parallels between the development of the ancient empires of the Old and New Worlds show that no innovation can compensate the shortage of fertile soil in the struggle to maintain high productivity of arable land. Disparaging attitude for such basic values as healthy soils quickly led to the collapse of one society after another.

With the publication of Bernard Palissy treatise "About various salts in agriculture", the soil began to be considered as a source of mineral nutrients for plants. At the beginning of the eighteenth century the idea of feeding plants with water arose, which was promoted by the famous chemist Jan Baptist van Hel- mont, which in general grew into the theory of water nutrition of plants. At the beginning of nineteenth century the idea of humus nutrition of plants made by A. Thaer arose, according to which plants assimilate organic matter of humus directly from the soil.

Polish scientist M. Oczapowski was a supporter of the theory of plant nutrition by humus. He presented the results of his research in a work on the classification of soils (Oczapowski, 1835).

To replace the humus idea, which eventually grew into theory, there is the idea of mineral nutrition of plants made by J. Liebig, who in his work "Chemistry in addition to agriculture and plant physiology" logically proved that terrestrial plants absorb mineral nutrients from the soil, which led to the development production of mineral fertilizers and contributed to a significant increase in crops. This was the beginning of the development of agricultural chemistry (Liebig at al., 1843; Rosenfeld, 2003).

In the middle of the $19^{\text {th }}$ century F. Fallou, G. Berendt, F. Richthofen's idea about the soil as a geological formation appeared. In 1837 C. Sprengel's book "Soil Science, or the Science of Soils" was published, in which the agrogeological direction in soil science was developed. Soil science was based on the idea of soil as an inert environment for plant growth (Tandarich et al., 1994).

In 1947, the Polish scientist M. Strzemski published an extensive review of the history of "scientific systematization of soils", in which he set out many general questions of the history of soil science, highlighting the periodization of the history of soil science from the Middle Ages till Thaer (Strzemski, 1947).

Well-known theorist of the history of science Polish scientist P. Malecki in a report at the 12th International Congress of History and Technology, speaking about the importance of this field of human knowledge, noted that to assess the present and predict the future is impossible without knowledge about the past (Malecki, 1971).

Agronomist F. Czarnomski (1852-1898), who worked in Krakow, in the book "Soil, its origin and types", published in 1900 in Polish, outlined the achievements of modern soil science and compared the outdated ideas of German agrogeologists with a new direction in the science of soils, created in Russia by Dokuchaev (Strzemski, 1955).

In 1907 M. M. Sibirtsev's book "Pedology” was published in Polish. Except M. M. Sibirtsev, the soils of Poland were studied by geologist K. Malewski. A significant role in the study of soils was played by the research of the founder of Polish soil science S. Miklaszewski (1874-1949), who created soil maps of Poland and Lithuania called "Map of soils of Kingdom of Poland", the author of the book "Soils of Poland" (1930). An important role in the study of soils in Poland was played by the publication of books in Polish by J. Tomaszewski (1884-1967), A. Musierowicz (1894-1966) and a specialist in forest and agronomic soil science F. Terlikowski (1885-1951), who was the first chairman of the Polish Society of Soil Scientists, founded in 1936. 


\section{Soil cartographic information}

The first attempts mapping of soils began in the early eighteenth century. A multi-page map of Eastern Europe (from the Baltic Sea to the Danube and the Dnieper) was compiled in 1806 by a famous Polish geologist, head of the Department of Industry and Crafts S. Staszic (1755-1826). This map is a sample of a complex geological-geomorphological-soil map. In many places, especially in the south, there is the sign chernozem (vegetative land) ("Terres vegetales"), the most southern places are marked as "Campi deserti" (wild steppes); there are signs of swampy and marly soils (Staszic, 1806). Historically, this stage of soil cartography, when they are shown together with the relief and rocks, is inevitable.

An eradicative change in ideas about the soil as an independent natural-historical body became the basis for the creation of a fundamental natural science - soil science. Based on the works of predecessors, in particular Kharkiv scientists N.D. Borysiak and I. F. Lewakovski, the basis for the development of a new direction of soil science - genetic soil science, published in the work of V. V. Dokuchaev's "Russian Chernozem", published in 1883 (Vysloužilová et al., 2016; Johnson et al., 2015). In recent decades, the emphasis in modern soil science has been made on ecological aspects. The inseparable connection between soil science and ecology is highlighted in numerous publications of scientists (Ettema et al., 2002; Eckmeier et al., 2007; White, 2013; Rowell, 2014; Gałka et al., 2016; Karczewska et al., 2017). Soil science has been enriched by some methods of ecology and a holistic approach to the study of the problem, and ecology has received from soil science a new object of study, which is still a separate organism. Such mutual enrichment was reflected in the development of the ideas of V. Vernadsky, G. Dobrovolsky, D. Binkley, D. Montgomery, M.A. Golubets, P. Skłodowski, R. Dębicki, S. Skiba, C. Kabała, Z. Zagórski, A. Mocek, V. Targulyan, J. Chojnicki, S. Balyuk, V. Medvedev, R. Bednarek, J. Kucharski, and others.

Soils are one of the most important storage of global biodiversity, beginning from microorganisms and ending with flora and fauna. Such diversity is crucial for the maintenance of soil functions and, therefore, soil-related ecosystem goods and services.

The accumulation of information about groups caused the need of the creation of a new form of its generalization and use - a database that is widely used to solve various problems, including mapping and pedosphere modeling (Brevik et al., 2016; Kabała et al., 2019). A database is a way of synergism of information, when one parameter increases the in formativeness of another and in general the in formativeness of the whole system.

Soils and soil cover of the Earth are special carriers and accumulators of information about the evolution of the biosphere, geosphere and society in time on the earth's surface. The soil memorize, notes in its stable properties information about the conditions and processes of its functioning and further changes over time. Thus, one of the perspective ways of development of soil science is the development of the concept of soil memory (Targulian and Goryachkin, 2008).

\section{Social soil science is the basis of the development of human civilization}

Soils mostly determine social well-being - an integrated indicator of the effectiveness of the social sphere, a reflection of social well-being, well-being, quality of life, an indicator of social security of the social system in general. In the process of forming a social space, priority is given to a human and a soil. Human is the main value for society. The social role of soil is its ability to create comfortable conditions for vital activity of society, namely to provide it with sufficient quality provision and raw materials for industry, to create favorable living conditions for mankind, in particular ecological (Pozniak et al., 2019).

World experience of land use shows that civilization continues to exist as long as it has enough productive soil to provide the population with provision. To maintain the collective wellbeing of people we need a reorientation of society fora longterm interest in soil protection, which should become a priority for human civilization.

At the same time, it should be noted that society is not good informed about the general condition, opportunities and problems of soil cover in modern conditions, but the very survival of people is largely determined by the attitude to soil not as a commodity but as an investment and cultural heritage. Such important problems of social development are considered by a new direction of soil science - social soil science. People's attitude to the soil is fundamental for the constant development of the society. Careful and tender attitude to the soil - is an inner need, the basis of high moral and ethical human behavior.

\section{Conclusions}

Based on modern scientific research, it can be argued that the soil is a complex multicomponent, open, multiphase, dynamic, spatial, energetic, informational, multifunctional system in the surface layer of weathering crust, which is the result of interaction of soil factors and forms a complex spatial organization of features and properties, has the ability of fertility and memory and has social significance.

\section{References}

Brevik, E.C., Calzolari, C., Miller, B.A., Pereira, P., Kabala, C., Baumgarten, A., Jordán, A., 2016. Soil mapping, classification, and pedologic modeling: History and future directions. Geoderma 264, 256-274. https:// doi.org/10.1016/j.geoderma.2015.05.017

Montgomery, D.R., 2007. Dirt: the erosion of civilizations. University of California Press, Berkeley, USA.

Darvin, C., 1881. The Formation of vegetable mould, trough the action of worms, with observation on their habits. John Murray, London. 
Eckmeier, E., Gerlach, R., Gehrt, E., Schmidt, M.W., 2007. Pedogenesis of chernozems in Central Europe - a review. Geoderma 139, 288-299. https://doi.org/10.1016/j.geoderma.2007.01.009

Ettema, C.H., Wardle, D.A., 2002. Spatial soil ecology. Trends in ecology \& evolution 17(4), 177-183. https://doi.org/10.1016/S01695347(02)02496-5

Gałka, B., Kabała, C., Karczewska, A., Sowiński, J., Jakubiec, J., 2016. Variability of soil properties in an intensively cultivated experimental field. Soil Science Annual 67(1), 10-16. https://doi.org/10.1515/ssa2016-0002

Johnson, D.L., Schaetzl, R.J., 2015. Differing views of soil and pedogenesis by two masters: Darwin and Dokuchaev. Geoderma 237, 176-189. https://doi.org/10.1016/j.geoderma.2014.08.020

Kabała, C., Charzyński, P., Chodorowski, et al., 2019. Polish Soil Classification, - principles, classification scheme and correlations. Soil Science Annual 70(2), 71-97. https://doi.org/10.2478/ssa-2019-0009

Karczewska, A., Kabała, C., 2017. Environmental risk assessment as a new basis for evaluation of soil contamination in Polish law. Soil Science Annual 68(2), 67-80. https://doi.org/10.1515/ssa-2017-0008

Liebig, J., Playfair, L., 1843. Chemistry in its application to agriculture and physiology. Taylor and Walton, London.

Oczapowski, M., 1835. Agronomia czyli nauka o gruntach, ich własnościach, wpływie na nie zewnętrznych okoliczności, oraz o klassyfikacyi ich ekonomicznej teoretyczno-praktycznie wyłożone. Merzbach, Warszawa.

Oczapowskim M., 1819. Zasady chemii rolniczey. Marcinowski, Wilno.

Pozniak, S.P., Havrysh, N.S., 2019. The role of soils in social development of society. Ukrainian Geographical Journal 2, 57-63. https://doi. org/10.15407/ugz2019.02.057
Rosenfeld, L., 2003. Justus Liebig and animal chemistry. Clinical chemistry 49(10), 1696-1707. https://doi.org/10.1373/49.10.1696

Rowell, D.L., 2014. Soil science: methods \& applications. Routledge, Taylor Francis Group, London, New York.

Staszic, S., 1806. Geological map of the territories of Poland, Moldavia, Transylvania and parts of Hungary and Wallachia. Warszawa.

Targulian, V.O., Goryachkin, S.V. 2008. Soil Memory: soil as a memory of biosphere-geosphere-anthroposphere interaction. Moscow.

Strzemski, M., 1947. Essay on the development of scientific taxonomy of soils. Materiały do poznania gleb Polski. Pamiętnik PINGW w Puławach 18, 25-45.

Strzemski, M., 1955. The forgotten Polish soil scientist Franciszek Czarnomski (1852-1898). Roczniki Gleboznawcze - Soil Science Annual 4, 251-254.

Tandarich, J.P., Sprecher, S.W., 1994. The intellectual background for the factors of soil formation. [In:] Amundson, R., Harden, J., Singer, M., Novak, V. (Eds.), Factors of soil formation: a fiftieth anniversary retrospective. Soil Science Society of America, Wisconsin, USA, 1-13. https://doi.org/10.2136/sssaspecpub33

Vysloužilová, B., Ertlen, D., Schwartz, D. and Šefrna, L., 2016. Chernozem. from concept to classification: A review. AUC Geographica 51(1), 85-95. https://doi.org/10.14712/23361980.2016.8

White, R.E., 2013. Principles and practice of soil science: the soil as a natural resource. Blackwell, John Wiley \& Sons.

Winiwarter, V., 2004. Breaking the sod: humankind, history and soil. Science 304, 1627-1629. https://doi.org/10.1126/science.1099893 